\title{
ANALISIS PERBANDINGAN EX-ANTE SCREENING DAN EX-POST MONITORING DALAM PENGELOLAAN RISIKO
}

\section{COMPARATIVE ANALYSIS APPLICATION OF EX-ANTE SCREENING AND EX-POST MONITORING IN RISK MANAGEMENT}

\author{
Yulianti Indah Pertiwi'a ${ }^{1 a}$. Rifqy Thantawi ${ }^{2 b}$ \\ 1aJurusan Ekonomi Islam Fakultas Perbankan Syariah Universitas Djuanda, Jl. Tol Ciawi No. 1 Bogor Kode \\ Pos 16720. \\ 2bJurusan Perbankan Syariah Fakultas Ekonomi Islam Universitas Djuanda, Jl. Tol Ciawi No. 1, Bogor Kode \\ Pos 16720 \\ Email : 1a y.indah07@gmail.com, 2b rifqythantawi@yahoo.com \\ (Diterima oleh Dewan Redaksi: Agustus) \\ (Dipublikasikan oleh Dewan Redaksi: Desember)
}

\begin{abstract}
This research purposes to determine the difference between ex-ante screening and expost monitoring in risk management in Islamic banks. Using qualitative methods of analysis techniques Model Miles and Huberman. Ex-ante screening process in an effort to finance risk management, financing both productive and consumptive at BNI Syariah Branch Bogor done with the principle of analysis 5C, 5P and 3R.In addition to the principle of such analysis, BNI Syariah Head Office also provides traffic light (guidelines for the business sector) in each branch office in the provision of financing, other supporting factors in the form of an audit of compliance with the system EFO (Electronic Financing Origination), and DPS. The process of ex-post monitoring BNI Syariah Branch Bogor done with credit checking, on desk monitoring, on-site monitoring and checking trade. A solving finance troubles is drawn on 3R application are rescheduling, reconditioning and restructuring, as for customers who do not have good faith to repay the installment will be charged with the termination of asset selling under hand and tender. From the two procedures, ex-ante screening is more important because it will determine the process and minimize the risk of financing.
\end{abstract}

Keywords : Ex-Ante Screening, Ex-Post Monitoring.

\section{ABSTRAK}

Penelitian ini bertujuan untuk mengetahui perbedaan antara ex-ante screening dan expost monitoring dalam pengelolaan risiko di bank syariah. Menggunakan metode kualitatif dengan teknikanalisis Model Miles and Huberman. Proses ex-ante screening dalam upaya pengelolaan risiko pembiayaan, baik pembiayaan produktif maupun konsumtif pada BNI Syariah Cabang Bogor dilakukan dengan prinsip analisis 5C, 5P dan 3R. Selain prinsip analisis tersebut, Kantor Pusat BNI Syariah juga memberikan traffic light (pedoman sektor usaha) pada setiap Kantor Cabang dalam pemberian pembiayaan, faktor pendukung lain berupa adanya audit kepatuhan dengan sistem EFO (Electronic Financing Origination), dan DPS. Proses ex-post monitoring BNI Syariah Cabang Bogor dilakukan dengan credit checking, on desk monitoring,on site monitoring dan trade checking. Penyelesaian permasalahan pembiayaan berupa penerapan R3 yaitu rescheduling, reconditioning dan restructuring, adapun nasabah yang tidak mempunyai iktikad baik untuk melunasi angsurannya maka dilakukan tindakan pemutusan 
hubungan dengan penjualan aset dibawah tangan dan lelang. Dari kedua prosedur tersebut, ex-ante screening merupakan proses terpenting karena akan menentukan dan meminimalisir risiko pembiayaan yang akan terjadi.

Kata kunci : Ex-Ante Screening, Ex-Post Monitoring.

Indah Pertiwi Yulianti. 2015. Analisis Perbandingan Ex-Ante Screening dan Ex-Antee Monitoring Dalam Pengelolaan Resiko. Jurnal Nisbah (2): 114-131.

\section{PENDAHULUAN}

Perbankan syariah mulai menunjukkan adanya kepercayaan masyarakat kepada layanan perbankan syariah, kepercayaan ini muncul karena bank syariah telah terbukti memberikan kesejahteraan masyarakat, terutama pada saat terjadinya krisis pada tahun 1998 (Rochman, 2010:2).

Perkembangan perbankan syariah juga didukung dengan adanya laju pertumbuhan aset perbankan syariah yang tetap lebih tinggi dibandingkan pertumbuhan aset perbankan secara nasional, pangsa perbankan syariah secara keseluruhan dengan memasukkan BPRS terhadap industri perbankan nasional meningkat dari $4,61 \%$ menjadi 4,93\%. Selain itu, pertumbuhan aset tersebut tetap diikuti pelaksanaan fungsi intermediasi yang optimal, hal ini tercermin pada tren pertumbuhan dan nominal pembiayaan BUS dan UUS yang lebih tinggi dibandingkan dana pihak ketiga, sebagaimana tergambar pada gambar berikut (Otoritas Jasa Keuangan, 2013 : 2):

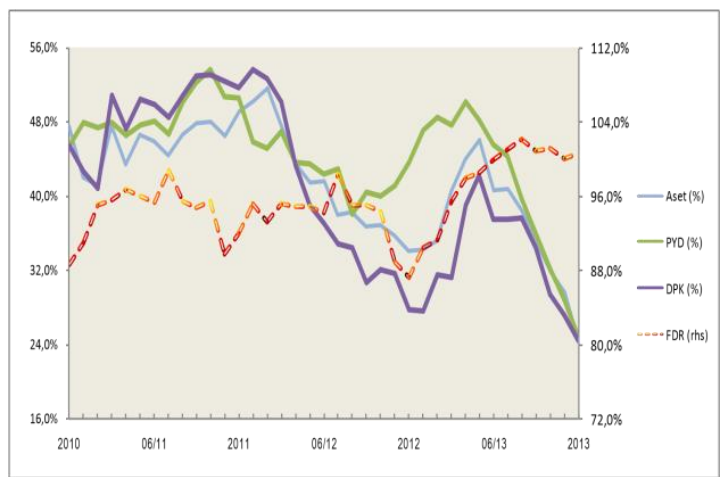

Gambar 1. Perkembangan Aset, DPK, PYD \& FDR Bank Syariah

Sumber : Laporan Perkembangan Keuangan Syariah Tahun 2013 -
Otoritas Jasa Keuangan (0JK)

Bank syariah berusaha mengimbangi peningkatan pembiayaan tersebut dengan berbagai instrumen keuangan syariah yang diterapkan dan selalu dikembangkan, semua itu bertujuan untuk memenuhi kebutuhan masyarakat dalam melakukan transaksinya. Di satu sisi, peningkatan yang terjadi memberikan banyak manfaat bagi lembaga keuangan syariah maupun masyarakat, namun peningkatan transaksi keuangan syariah juga telah menimbulkan potensi masalah atau risiko yang lebih tinggi, terutama bagi sistem keuangan syariah yang belum memiliki rambu-rambu yang memadai untuk memastikan bahwa setiap transaksi dapat dilakukan dengan aman (Buchori,et al, 2003). Salah satu risiko yang dihadapi bank syariah adalah risiko pembiayaan, hal ini terlihat dari peningkatan NPF (Non Performing Financing) dari tahun sebelumnya yang tergambar pada gambar berikut :

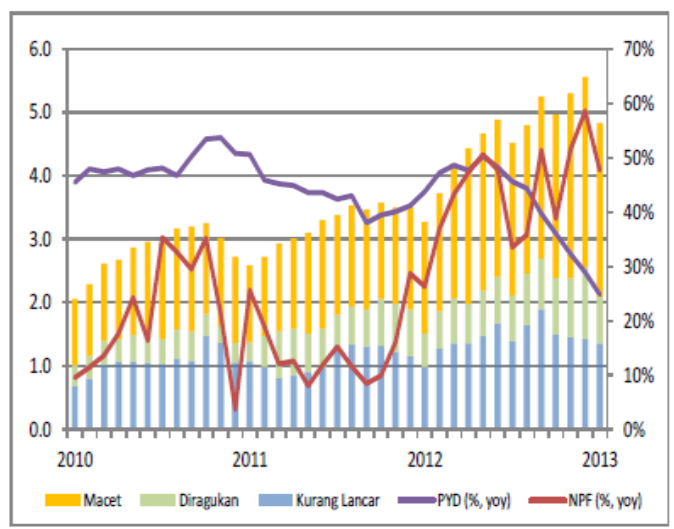

Gambar 2. Perkembangan NPF BUS dan UUS Sumber : Laporan Perkembangan Keuangan Syariah Tahun 2013 -

Otoritas Jasa Keuangan (OJK)

Risiko pembiayaan yang dihadapi BUS dan UUS diperkirakan relatif 
meningkat dibandingkan tahun sebelumnya, meskipun masih dalam taraf yang terkendali. Kondisi tersebut tercermin dari meningkatnya pembiayaan non performing dalam setahun terakhir mencapai $47,7 \%$ (уоу), lebih tinggi dari tahun 2012 sebesar 26,3\% (Gambar 1.2). Meskipun pangsa pembiayaan non performing kurang dari $5 \%$ atau masih dalam batas yang terkendali, namun pertumbuhannya yang cukup signifikan perlu diperhatikan dan dimitigasi lebih lanjut dalam kerangka manajemen risiko yang lebih komprehensif (Otoritas Jasa Keuangan, 2013).

Fenomena tersebut mengindikasikan perlunya manajemen risiko yang tepat bagi instrumen maupun transaksi yang ditawarkan bank syariah, karena tidak ada yang bisa memastikan keadaan yang terjadi dimasa yang akan datang (Rochman, 2010). Bank syariah sebagaimana bank pada umumnya akan menghadapi tingkat risiko yang cukup beragam sesuai dengan jenis instrumen atau transaksi yang dihadapi. Secara umum bank menggunakan 2 cara untuk mengurangi risiko yaitu ex-ante screening dan ex-post monitoring.

Ex-ante screening merupakan analisis sebelum deal terjadi yang hasilnya berupa besarnya risiko dan kemungkinan terjadinya, sebagai dasar dalam pricing maupun credit rationing. Adapun ex-post monitoring merupakan monitoring setelah deal terjadi baik secara individu maupun portofolio dan memberikan rekomendasi kebijakan bagi management untuk mengambil kebijakan sesuai dengan guidelines yang ada hedging (Trihantana, 2014:6-7).

\section{MATERI DAN METODE}

Jenis penelitian yang dilakukan pada penelitian ini adalah penelitian deskriptif kualitatif. Penelitian deskriptif kualitatif yang digunakan pada penelitian ini dimaksudkan untuk memperoleh informasi mengenai exante screening dan ex-post monitoring dalam pengelolaan risiko di BNI Syariah Cabang Bogor. Selain itu, dengan pendekatan kualitatif diharapkan dapat diungkapkan situasi dan permasalahan yang dihadapi dalam pengelolaan risiko di bank tersebut.

Populasi untuk penelitian ini adalah BNI Syariah. Sampel dari penelitian ini adalah BNI Syariah Cabang Bogor. Sampel ini menggunakan teknik sampling purposive yaitu teknik penentuan sampel dengan pertimbangan tertentu (Sugiyono, 2010). Pertimbangan tertentu dalam penelitian ini yaitu informan yang dianggap mengetahui tentang ex-ante screening dan ex-post risiko BNI Syariah Cabang Bogor mengenai penerapan exante screening dan ex-post monitoring dalam upaya mengurangi terjadinya risiko.

Teknik pengumpulan data dalam penelitian ini berupa :

1. Teknik wawancara atau interview

Merupakan teknik pengumpulan data yang didapat dari proses tanya jawab dengan pihak bank, sehingga dapat menginterprestasikan situasi dan fenomena yang terjadi. Wawancara ini dilakukan secara langsung kepada divisi manajemen risiko BNI Syariah Cabang Bogor mengenai penerapan ex-ante screening dan ex-post monitoring dalam upaya mengurangi terjadinya risiko.

2. Dokumentasi

Dokumentasi merupakan teknik pengumpulan data berdasarkan catatan peristiwa yang sudah berlalu, baik itu proses maupun kasus operasional ex-ante screening dan ex-post monitoring dalam melaksanakan manajemen risiko. Dari data tersebut dapat diketahui antara ex-ante screening dan ex-post monitoring, manakah yang lebih 
efektif digunakan di BNI Syariah Cabang Bogor sebagai upaya mengurangi terjadinya risiko.

3. Teknik kepustakaan

Pengumpulan data ini bersumber dari berbagai referensi seperti jurnal, buku, majalah, artikel, koran, internet dan lain sebagainya yang mendukung data penelitian ini.

Jenis data yang digunakan dalam penelitian ini terdiri atas data primer dan data sekunder. Data-data tersebut diperoleh melalui :

1. Data Primer, yaitu data yang dikumpulkan sendiri oleh peneliti dari objek penelitian di lapangan, berupa hasil wawancara dan observasi yang terdiri atas gambaran umum manajemen risiko yang digunakan BNI Syariah Cabang Bogor.

2. Data Sekunder, yaitu data yang diperoleh melalui penelitian pustaka, baik itu dari buku-buku, jurnal, majalah, internet maupun koran yang ada hubungannya dengan masalah yang akan diteliti, yaitu ex-ante screening dan ex-post monitoring sebagai cara mengurangi adanya risiko.

Model Miles and Huberman saat penelitian berlangsung dan setelah pengumpulan data periode tertentu. Aktivitas dalam analisis data yaitu data reduction, data display, dan conclusion drawing/verification. Langkah-langkah analisis ditunjukkan pada model interaktif dalam analisis data berikut :

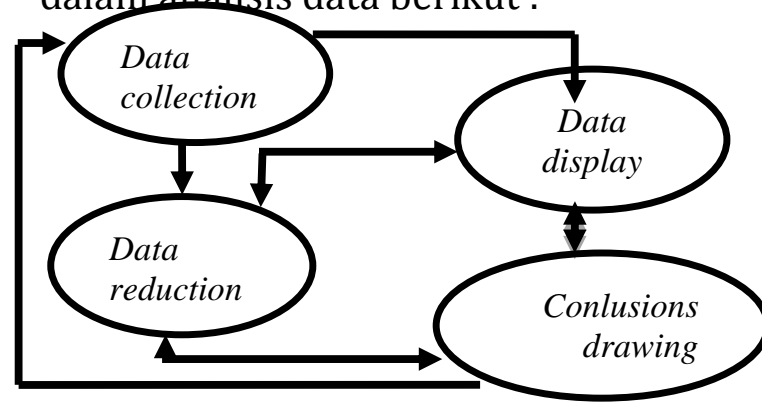

Gambar 3. Komponen dalam analisis data (interactive model)

Sumber : Sugiyono, 2010:431
Berdasarkan gambar analisis data tersebut maka uraian untuk penelitian ini sebagai berikut :

1. Data Collection (mengumpulkan data)

Dalam penelitian ini, data mengenai ex-ante screening dan ex-post monitoringdikumpulkan sesuai dengan teknik pengumpulan data, selanjutnya data disiapkan untuk direduksi.

2. Data reduction (mereduksi data)

Mereduksi data berarti merangkum, memilih hal-hal pokok serta penting kemudian dicari tema dan polanya (Sugiyono, 2012). Pada tahap ini peneliti memilah informasi mana yang relevan dan mana yang tidak relevan mengenai ex-ante screening dan ex-post monitoring untuk selanjutnya dijadikan data penelitian. Setelah direduksi data $e x-$ ante screening dan ex-post monitoring akan mengerucut, semakin sedikit dan mengarah ke inti permasalahan sehingga mampu memberikan gambaran yang lebih jelas mengenai perbandingan penerapan ex-ante screening dan expost monitoring.

3. Data display (penyajian data)

Setelah dilakukan reduksi data, langkah selanjutnya adalah menyajikan data ex-ante screening dan ex-post monitoring dalam bentuk tabel atau uraian penjelasan yang bersifat deskriptif, sehingga data akan mudah dipahami.

4. Conlusions drawing/verification Langkah selanjutnya dalam analisis data kualitatif menurut Miles and Huberman merupakan penarikan kesimpulan dan verifikasi. Setelah melakukan serangkaian metode dan analisis yang digunakan untuk penelitian ini maka dapat ditarik kesimpulan dan verifikasi dari penelitian ini berupa hasil perbandingan penerapan ex-ante 
screening dan ex-post monitoring dalam pengelolaan risiko di BNI Syariah Cabang Bogor.

\section{HASIL DAN PEMBAHASAN}

BNI Syariah memiliki beberapa prosedur dalam meminimalisir pembiayaan bermasalah berupa analisis pembiayaan sebelum deal terjadi yang dikenal dengan istilah ex-ante screening, dan maintenance/monitoring pembiayaan setelah deal terjadi yang dikenal dengan istilah ex-post monitoring, adapun penjelasannya sebagai berikut:

\section{Proses Ex-Ante Screening}

Menurut pemaparan analis pembiayaan produktif atau unit SME (Small Medium Enterprise), proses ex-ante screening akan dimulai dengan proses pengajuan pembiayaan dari pihak nasabah, berikut merupakan prosedur pengajuan pembiayaan pada BNI Syariah Cabang Bogor :

\section{a. Prosedur Pengajuan Pembiayaan}

Mekanisme pangajuan pembiayaan pada BNI Syariah Cabang Bogor akan dijelaskan berikut ini :

1) Permohonan pembiayaan

2) Pengumpulan persyaratan dan analisis

\section{b. Analisis Pembiayaan}

Data yang sudah diinput kedalam sistem EFO (Electronic Financing Origination) akan dianalisis oleh unit prosesing. Menurut penjelasan analis pembiayaan produktif BNI Syariah Cabang Bogor, analisis pembiayaan untuk kelayakan memperoleh pembiayaan menggunakan teknik analisis 5C, 5P dan 3R dengan proses analisis berupa kelengkapan persyaratan dan wawancara nasabah. Berikut merupakan penjelasan analisis 5C:

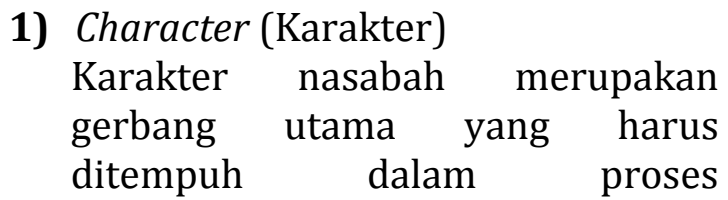
pembiayaan, hal ini dilakukan untuk mengetahui baik buruknya karakter nasabah, baik dalam kehidupan pribadi maupun dalam lingkungan usaha. Untuk memenuhi tujuan tersebut maka BNI Syariah Cabang Bogor melakukan hal-hal sebagai berikut:

a) Verifikasi data

b) Melakukan wawancara dengan nasabah

c) BI checking

Analisis pembiayaan ditekankan dalam Al-Qur'an Surat Al-Anfal ayat 27 yaitu:

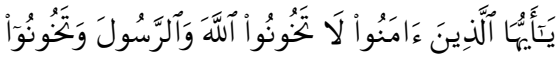

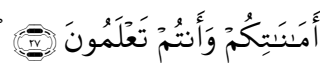

Artinya : "Hai orang-orang yang beriman, janganlah kamu mengkhianati Allah dan Rasul (Muhammad) dan (juga) janganlah kamu mengkhianati amanat-amanat yang dipercayakan kepadamu, sedang kamu mengetahui" (QS. Al Anfal : 27).

\section{2) Capacity (Kapasitas)}

Analisis kapasitas nasabah digunakan untuk mengetahui kemampuan nasabah dalam berbisnis termasuk kemampuan dalam menghasilkan kas atau setara kas dan untuk menentukan nasabah yang tepat menerima pembiayaan, sehingga ada kepastian nasabah akan memenuhi kewajibannya kepada BNI Syariah Cabang Bogor, sebagaimana dijelaskan dalam AlQur'an Surat An-Nisa ayat 58 yaitu : 


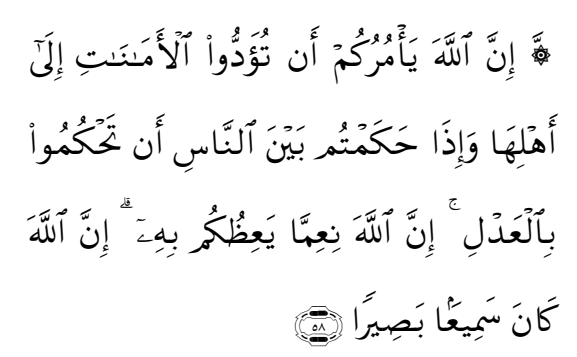

Artinya: "Sesungguhnya Allah menyuruh kamu menyampaikan amanat kepada yang berhak menerimanya, dan (menyuruh kamu) apabila menetapkan hukum di antara manusia supaya kamu menetapkan dengan adil. Sesungguhnya Allah memberi pengajaran yang sebaik-baiknya kepadamu. Sesungguhnya Allah adalah Maha mendengar lagi Maha melihat" (QS. AnNisa : 58).

\section{3) Capital (Modal)}

Analisa modal digunakan untuk mengetahui keyakinan nasabah terhadap usahanya sendiri.

\section{4) Condition (Kondisi)}

Analisa ini diarahkan untuk mengetahui kondisi sekitar yang secara langsung maupun tidak langsung berpengaruh terhadap usaha calon nasabah, seperti keadaan ekonomi yang akan mempengaruhi

perkembangan usaha calon nasabah, prospek usaha di masa yang akan datang, perbandingan kondisi usaha calon nasabah dengan usaha sejenis, dan kebijakan pemerintah yang dapat berpengaruh tehadap prospek industri dari perusahaan calon nasabah terkait didalamnya.

5) Collateral (Jaminan)
Jaminan utama adalah keyakinan tentang willingness and ability (kemauan dan kemampuan) dari pihak bank terhadap nasabah yang diberi pembiayaan. Sedangkan agunan hanya merupakan jaminan tambahan atau penunjang dari jaminan utama, hal tersebut didasarkan pada fungsi utama dari bank syariah sebagai lembaga intermediasi.

BNI Syariah Cabang Bogor menetapkan standar besarnya nilai agunan ditentukan oleh jumlah pembiayaan, nilai agunan harus melebihi besarnya pembiayaan yang diberikan yaitu sebesar 110-120\% dari total pembiayaan yang diberikan, seperti yang tercantum pada PBI Nomor 14/20/PBI/2012 Pasal 6 bahwa besarnya agunan untuk Fasilitas Pendanaan Jangka Pendek Syariah (FPJS) dimulai dari agunan berupa SBIS $100 \%$, agunan berupa SBSN 105\%, agunan berupa surat berharga 120\% dan agunan berupa aset pembiayaan $200 \%$.

Jaminan yang dimaksud harus mampu meng-cover risiko bisnis calon nasabah. Analisa yang dilakukan BNI Syariah Cabang Bogor antara lain :

a) Meneliti kepemilikan jaminan yang diserahkan.

b) Mengukur dan memperkirakan stabilitas harga jaminan dimaksud.

c) Memperhatikan kemampuan untuk dijadikan uang dalam waktu relatif singkat tanpa harus mengurangi nilainya.

d) Memperhatikan pengikatnya, sehingga secara legal BNI Syariah Cabang Bogor dapat dilindungi.

e) Rasio jaminan terhadap jumlah pembiayaan. 
Adanya jaminan atas sebuah kewajiban juga sudah dijelaskan dalam Al-Qur'an Surat Al-Baqarah ayat 283 yaitu :

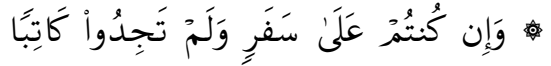

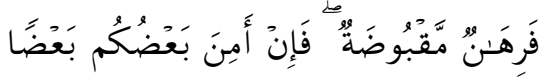

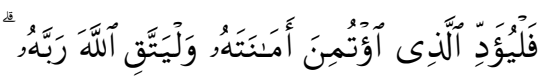

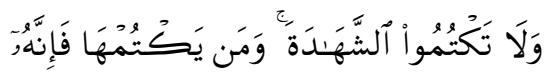

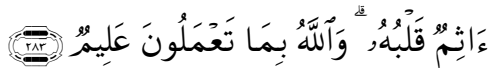

Artinya : "Jika kamu dalam perjalanan (dan bermu'amalah tidak secara tunai) sedang kamu tidak memperoleh seorang penulis, Maka hendaklah ada barang tanggungan yang dipegang (oleh yang berpiutang), akan tetapi jika sebagian kamu mempercayai sebagian yang lain, Maka hendaklah yang dipercayai itu menunaikan amanatnya (hutangnya) dan hendaklah ia bertakwa kepada Allah Tuhannya; dan janganlah kamu (para saksi) Menyembunyikan persaksian. dan Barangsiapa yang menyembunyikannya, Maka Sesungguhnya ia adalah orang yang berdosa hatinya; dan Allah Maha mengetahui apa yang kamu kerjakan" (QS. AlBaqarah ayat 283).

Seluruh prosedur ex-ante screening BNI Syariah Cabang Bogor sudah sesuai dengan Undang-Undang Perbankan Syariah Pasal 23 dan PBI Nomor 13/13/PBI/2011 Pasal 8 dan 9 yang mengatur adanya analisis sebelum diberikannya pembiayaan, seperti dijelaskan pada ayat 1 yaitu "Bank syariah dan/atau UUS harus mempunyai keyakinan atas kemauan dan kemampuan calon nasabah penerima fasilitas untuk melunasi seluruh kewajiban pada waktunya, sebelum Bank Syariah dan/ atau UUS menyalurkan dana kepada nasabah penerima fasilitas". Untuk mendapatkan keyakinan maka bank syariah wajib melakukan penilaian yang seksama terhadap watak, kemampuan, modal, agunan dan prospek usaha dari calon nasabah penerima fasilitas (character, capacity, capital, collateral, condition). Pada Pasal 36 Undang-Undang Perbankan Syariah diatur pula bahwa "Dalam memberikan pembiayaan dan melakukan kegiatan usaha lainnya, Bank Syariah dan UUS wajib menempuh cara-cara yang tidak merugikan Bank Syariah dan UUS dan kepentingan nasabah yang mempercayakan dananya", sehingga bank syariah dalam memberikan pembiayaan wajib mempunyai keyakinan atas kemauan dan kemampuan dari nasabah penerima fasilitas.

Adapun untuk teknik analisis 5P (personality, purpose, prospect, payment dan party) dan 3R (return, repayment dan risk bearing activity), kedua teknis analisis tersebut dapat diketahui dengan berkas-berkas persyaratan dan hasil wawancara calon nasabah.

\section{Perbedaan Prosedur Pembiayaan Konsumtif dan Produktif \\ 1) Pembiayaan Konsumtif}

Prosedur selanjutnya pada pembiayaan komsumtif yaitu marketing officer menyerahkan proses analisis pembiayaan kepada unit prosesing, setelah itu marketing officer juga akan menyalurkannya/submit kepada sentra taksasi yang merupakan bagian/unit yang terpisah untuk melakukan appraisal/surveinilai jaminan. Ketika bagian taksasi sudah melakukan appraisal nilai jaminan maka selanjutnya akan diproses oleh unitprosesing kembali untuk menentukan kesimpulan dari rangkaian 
proses analisis, dan selanjutnya dikeluarkan keputusan dari bisnis manajer atau pimpinan cabang (sesuai dengan kewenangan pemutus). Setelah KPP (Komite Pemutus Pembiayaan) memberikan keputusan deal atas pembiayaan nasabah, maka proses selanjutnya diberikan kepada unit option untuk dibuatkan SK (Surat Keputusan) dan akad, yang kemudian dilanjut dengan pencairan pembiayaan.

Untuk jangka waktu pengajuan pembiayaan sampai dengan keputusan pembiayaan, baik konsumtif maupun produktif dihitung dengan SLA (Service Level Agreement), SLA (Service Level Agreement)akan dihitung dimulai dari lengkapnya persyaratan/berkas pengajuan pembiayaan nasabah, untuk SLA (Service Level Agreement)BNI Syariah Cabang Bogor itu rata-rata sekitar 3-4 hari dengan maksimal SLA (Service Level Agreement) selama 5 hari, tergantung dari proses analisa pembiayaan. Biasanya BNI Syariah melakukan analisa dengan SLA (Service Level Agreement) cepat itu pada calon nasabah yang mempunyai fixed income karena tidak adanya pendapatan yang berfluktuatif, berbeda dengan pengusaha yang selalu mengalami fluktuatif dalam pendapatannya.

Secara garis besar proses pembiayaan konsumtif BNI Syariah Cabang Bogor sebagai berikut :

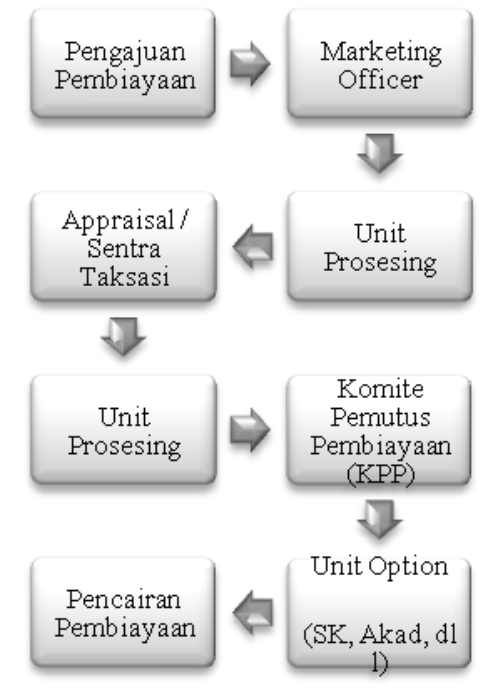

Gambar 4. Alur Pembiayaan Konsumtif BNI Syariah Cabang Bogor

Sumber : Diolah dari hasil wawancara

Sesuai gambar diatas dapat dilihat bahwa proses pembiayaan konsumtif BNI Syariah Cabang Bogor meliputi beberapa unit, antara lain:
a) Marketing officer
b) Unit prosesing (analisis pembiayaan)
c) Appraisal/sentra taksasi
d) KPP (Komite Pemutus Pembiayaan)
e) Unit option

\section{2) Pembiayaan produktif}

Berbeda dengan pembiayaan konsumtif, pembiayaan produktif dipegang oleh unit SME (Small Medium Enterprise) atau analis pembiayaan produktif, SME (Small Medium Enterprise) merupakan unit pembiayaan produktif yang mempunyai tugas mencari prospek pembiayaan, menganalisis dan juga memonitoring awal nasabah pembiayaan. Setelah dianalisis oleh SME (Small Medium Enterprise) dan menghasilkan kesimpulan analisis, selanjutnya hasil analisis tersebut diajukan kepada KPP (Komite Pemutus Pembiayaan) dalam hal ini pimpinan cabang, setelah adanya keputusan deal maka akan dibuatkan SK (Surat Keputusan) dan akad dengan pihak nasabah, yang dilanjut dengan pencairan pembiayaan.

Secara garis besar proses pembiayaan produktif BNI Syariah Cabang Bogor sebagai berikut:

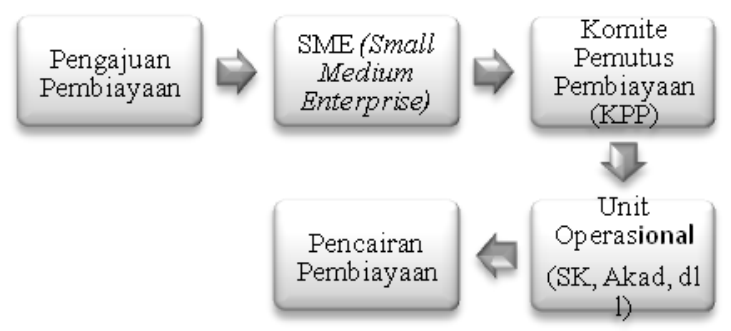

Gambar 5. Alur Pembiayaan Produktif BNI Syariah Cabang Bogor Sumber : Diolah dari hasil wawancara 
Sesuai gambar diatas dapat dilihat bahwa proses pembiayaan produktif BNI Syariah Cabang Bogor meliputi beberapa unit, antara lain :
a) SME (Small Medium Enterprise)
b) KPP (Komite Pemutus Pembiayaan)
c) Unit operasional

\section{d. Strategi Mitigasi Risiko Analisis Pembiayaan}

Analisis pembiayaan merupakan aspek penting dalam menyeleksi dan meminimalisir risiko yang mungkin terjadi, BNI Syariah Cabang Bogor mempunyai beberapa strategi dalam menganalisis pengajuan pembiayaan, khususnya pembiayaan produktif yang layak untuk diberikan pembiayaan, yaitu:

1) Kantor Pusat BNI Syariah memberikan traffic light pembiayaan kepada setiap Kantor Cabang, dengan ketentuan bisnis sektor apa saja yang mempunyai prospek baik dan berisiko pada saat itu. Sehingga setiap Kantor Cabang mempunyai panduan, sektor mana saja yang lampu hijau dalam arti aman, lampu kuning dan lampu merah, untuk traffic light selalu ada perubahan setiap 6 bulan sekali.

2) BNI Syariah mempunyai suatu perangkat audit kepatuhan pada bagian atau unit risiko dan kepatuhan, unit ini memastikan bahwa risiko ketidakpatuhan dalam proses pemberian pembiayaandapat diketahui sebelum suatu fasilitas pembiayaan dikomitekan, sehingga kerugian financial akibatketidakpatuhan dapat dimitigasi. Untuk pemantauan kepatuhan terhadap operasional BNI Syariah dilakukan oleh direktur kepatuhan, dengan membawahi divisi audit.

3) Selain perangkat kepatuhan, bank syariah termasuk BNI Syariah juga memiliki DPS (Dewan Pengawas
Syariah) yang mengawasi operasional BNI Syariah agar sesuai dengan prinsip syariah

\section{e. Hambatan dalam Proses Analisis Pembiayaan}

Berikut merupakan beberapa hambatan dalam proses analisis pembiayaan :

1) Adanya ketidakterbukaan nasabah dalam mendeskripsikan kondisi usahanya, sehingga dapat disimpulkan tidak adanya iktikad yang baik dalam mengajukan pembiayaan pada BNI Syariah Cabang Bogor.

2) Adanya nasabah yang tidak secara langsung memenuhi persyaratan pembiayaan, sehingga butuh waktu yang lama untuk BNI Syariah Cabang Bogor memulai analisis pembiayaan.

Lamanya pengumpulan persyaratan pembiayaan akan menghambat proses analisis pembiayaan, maka sebaiknya BNI Syariah Cabang Bogor membuat batas waktu maksimum bagi calon nasabah untuk melengkapi persyaratan yang ditentukan.

\section{Proses Ex-Post Monitoring}

Proses ex-post monitoring atau monitoring setelah pembiayaan diberikan harus dilaksanakan oleh BNI Syariah Cabang Bogor, hal ini dilaksanakan demi kelancaran angsuran/usaha yang dijalankan nasabah. Sebagaimana dijelaskan dalam Al-Qur'an Surat Al-An'am ayat 69 yaitu :

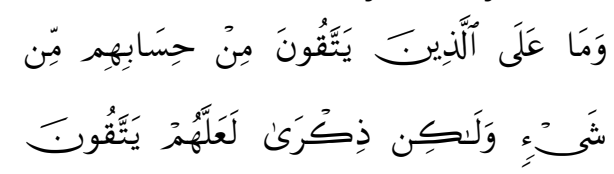

Artinya : "dan tidak ada pertanggungjawaban sedikitpun atas orang-orang yang bertakwa terhadap dosa mereka; akan tetapi (kewajiban mereka ialah) mengingatkan agar mereka 
bertakwa" (QS. Al An'am ayat 69).

Ayat tersebut menerangkan bahwa setiap manusia mempunyai kewajiban untuk saling mengingatkan dalam hal kebaikan/ketakwaan, hal ini mengimplikasikan pula bahwa setiap pembiayaan juga harus disertai dengan proses monitoring demi menjaga dan mengawasi usaha nasabah dari hal-hal yang tidak diharapkan. Berikut merupakan prosedur monitoring BNI Syariah Cabang Bogor :

\section{a. Monitoring Pembiayaan Konsumtif dan Produktif}

Menurut pemaparan supervisor unit recovery atau pembiayaan bermasalah, proses ex-post monitoring BNI Syariah Syariah Cabang Bogor akan melakukan pengelompokkan kriteria kolektibilitas nasabah, sebagaimana dijelaskan pada tabel berikut :

Tabel 1. Kriteria Kolektibilitas BNI Syariah Cabang Bogor

\begin{tabular}{|c|c|c|c|}
\hline Jenis & $\begin{array}{l}\text { Kategor } \\
\text { i }\end{array}$ & Keterangan & $\begin{array}{l}\text { Unit } \\
\text { Penanga } \\
\text { nan } \\
\end{array}$ \\
\hline $\begin{array}{l}\text { Kolekt } \\
\text { ibilitas } \\
1\end{array}$ & $\begin{array}{l}\text { Pembiay } \\
\text { aan } \\
\text { lancar }\end{array}$ & $\begin{array}{l}\text { Pembayaran } \\
\text { angsuran } \\
\text { pembiayaan } \\
\text { sesuai dengan } \\
\text { jadwal yang telah } \\
\text { ditetapkan. }\end{array}$ & $\begin{array}{l}\text { Bagian } \\
\text { collection } \\
\text { dan unit } \\
\text { SME } \\
\text { (Small } \\
\text { Medium }\end{array}$ \\
\hline $\begin{array}{l}\text { Kolekt } \\
\text { ibilitas } \\
2\end{array}$ & $\begin{array}{l}\text { Pembiay } \\
\text { aan } \\
\text { dalam } \\
\text { perhatia } \\
\text { n khusus }\end{array}$ & $\begin{array}{l}\text { Jika nasabah } \\
\text { mempunyai } \\
\text { tunggakan } \\
\text { angsuran dalam } \\
\text { jangka waktu 1- } \\
90 \text { hari dari } \\
\text { jadwal yang telah } \\
\text { ditetapkan. }\end{array}$ & $\begin{array}{l}\text { Enterpris } \\
\text { e) }\end{array}$ \\
\hline Kolekt & & Jika nasabah & Unit \\
\hline ibilitas & & mempunyai & Recovery \\
\hline 3 & $\begin{array}{l}\text { Pembiay } \\
\text { aan } \\
\text { kurang } \\
\text { lancer }\end{array}$ & $\begin{array}{l}\text { tunggakan } \\
\text { angsuran dalam } \\
\text { jangka waktu 91- } \\
120 \text { hari dari } \\
\text { jadwal yang } \\
\text { telah ditetapkan. }\end{array}$ & \\
\hline $\begin{array}{l}\text { Kolekt } \\
\text { ibilitas } \\
4\end{array}$ & $\begin{array}{l}\text { Pembiay } \\
\text { aan } \\
\text { diraguka }\end{array}$ & $\begin{array}{l}\text { Jika nasabah } \\
\text { mempunyai } \\
\text { tunggakan }\end{array}$ & \\
\hline
\end{tabular}

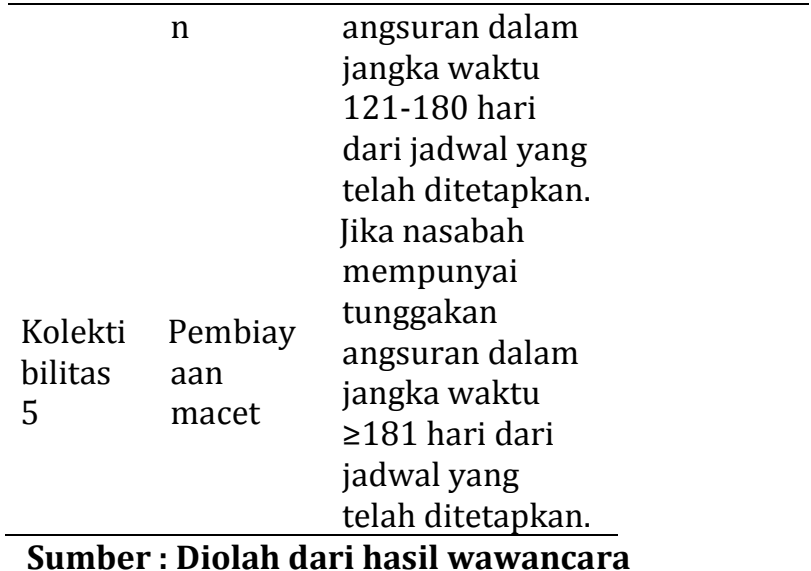

Beberapa tahapan monitoring, monitoring awal yang dilakukan BNI Syariah Cabang Bogor berupa pemantauan lancar atau tidaknya angsuran nasabah yang disetorkan. Monitoring awal pembiayaan konsumtif hanya dilakukan dengan pemantauan angsuran oleh bagian collection, sedangkan untuk pembiayaan produktif monitoring dilakukan oleh unit SME (Small Medium Enterprise) berupa pemantauan angsuran dan survei langsung pada usaha nasabah yang dilakukan secara berkala setiap bulannya. Setelah monitoring awal, BNI

Penetapan ketentuan kreteria golongan pembiayaan bermasalah di BNI Syariah Cabang Bogor sudah sesuai dengan Lampiran Surat Edaran Bank Indonesia Nomor 13/10/PBI/DPbS tanggal 13 April 2011 dan PBI Nomor 13/13/PBI/2011 Pasal 8 ayat 2 tentang Penilaian Kualitas Aktiva bagi Bank Umum Syariah dan Unit Usaha Syariah yang berdasarkan kemampuan membayar.

Pada kolektibilitas 1 dan 2 penanganan masih ditangani oleh unit prosesing, sedangkan pada kolektibilitas 3 , 4 dan 5 penanganan akan dipindahkan kepada unit recovery. Adapun upaya-upaya yang dilakukan BNI Syariah Cabang Bogor dalam menangani tahap awal pembiayaan bermasalah sebagai berikut:

1) Sms Blas 
Merupakan strategi BNI Syariah Cabang Bogor dalam upaya mengingatkan jadwal angsuran/jadwal jatuh tempo nasabah pembiayaan.

\section{2) Booming Call}

Merupakan strategi lanjutan BNI Syariah Cabang Bogor ketika nasabah tidak merespon/mengabaikan sms blas yaitu dengan cara menelepon nasabah untuk mengingatkan kembali jadwal jatuh tempo angsuran nasabah.

3) Surat Teguran/somasi

Merupakan peringatan setelah dilakukan tindakan sms blas dan booming call, surat peringatan ini diberikan dengan tahap SP1, SP2 dan SP3.

Pada saat SP2, BNI Syariah Cabang Bogor akan melakukan survei lapangan atau on site untuk melihat kondisi usaha yang dijalankan, apakah usaha tersebut mengalami kegagalan atau mungkin ada hambatan yang terjadi sehingga nasabah belum membayar angsurannya pada BNI Syariah Cabang Bogor.

Secara garis besar proses monitoring yang dilakukan BNI Syariah Cabang Bogor sebagai berikut:

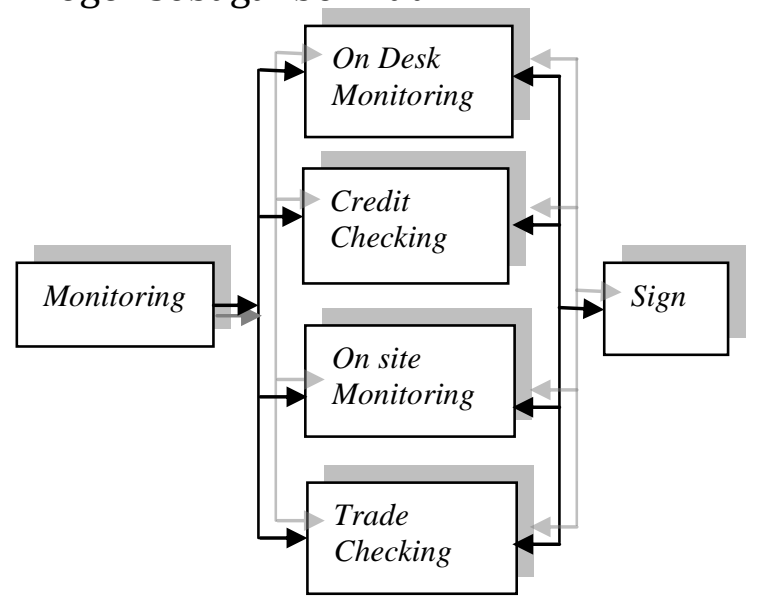

Gambar 6. Monitoring BNI Syariah Cabang Bogor

Sumber : Diolah dari hasil wawancara

Monitoring ini dilakukan untuk mengetahui indikasi-indikasi yang merupakan potensial risk bagi pembiayaan BNI Syariah Cabang Bogor.
Secara garis besar monitoring ini dibedakan menjadi :

\section{a. On Desk Monitoring}

Pemantauan ini dilakukan oleh BNI Syariah Cabang Bogor melalui instrumen-instrumen administratif, laporan perkembangan usaha, laporan produksi, pembelian, pemasaran, penjualan, persediaan barang, piutang, biaya, anggaran dan neraca kerja usaha nasabah, neraca, laba rugi, sumber/penggunaan dana, dokumen jaminan, jenis dan jangka waktu pembiayaan serta kelengkapan dokumen lainnya.

\section{b. Credit Checking}

Merupakan pemantauan angsuran yang dilakukan BNI Syariah Cabang Bogor dengan memanfaatkan informasi yang berkaitan dengan kelancaran utang piutang, baik untuk fasilitas yang diberikan oleh bank maupun bank lain.

\section{c. On Site Monitoring}

Dalam hal ini BNI Syariah Cabang Bogor turun langsung ke lapangan melihat kondisi usaha nasabah baik sebagian atau menyeluruh. Hal ini dilakukan untuk mengetahui dan membuktikan apakah terjadi ketidaksesuaian antara laporan-laporan dan kondisi fisik dari kegiatan usaha nasabah karena kegiatan menurut admninstrasi harus sesuai dengan fisik kegiatan usaha nasabah tersebut. On site monitoring juga dilakukan ketika terjadi angsuran yang tidak seimbang (fluktuatif dalam jadwal angsuran), BNI Syariah Cabang Bogor tanpa harus meminta izin terlebih dahulu akan melakukan on site monitoring/sign visit, hal itu diperkenankan bagi BNI Syariah Cabang Bogor karena pernyataan tersebut sudah tertera dalam Surat Keputusan (SK) pembiayaan yang disepakati oleh nasabah. 


\section{d. Trade Checking}

Merupakan pemantauan kondisi usaha nasabah dengan memanfaatkan informasi yang berasal dari pemasok, distributor, pesaing, asosiasi industri, atau mitra bisnis yang lainnya. Hal ini dilakukan BNI Syariah Cabang Bogor untuk mengetahui secara jelas kondisi usaha nasabah ketika dirasakan adanya gejala penyimpangan, baik dalam kondisi usaha maupun ketepatan angsuran.

\section{b. Mitigasi Risiko BNI Syariah Cabang Bogor Terhadap Pembiayaan Bermasalah}

Penerapan manajemen risiko bagi Bank Umum Syariah (BUS) dan Unit Usaha Syariah (UUS) sudah diatur dalam PBI Nomor 13/23/PBI/2011 sehingga setiap bank syariah berusaha untuk mematuhi aturan yang ada, BNI Syariah Cabang Bogor juga melakukan hal yang sama karena setiap pembiayaan yang diajukan nasabah kepada BNI Syariah Cabang Bogor mempunyai risiko masing-masing, sehingga diperlukan strategi untuk memitigasi/mengelola risiko tersebut. Menurut pemaparan analis SME (Small Medium Enterprise), ada beberapa acuan yang digunakan BNI Syariah Cabang Bogor dalam memantau risiko yang mungkin terjadi, yaitu:

1) First Way Out

Merupakan mitigasi berupa monitoring angsuran nasabah.

2) Second Way Out

Second way out dilakukan jika first way out tidak bisa berjalan karena beberapa faktor, second way out dijalankan sesuai dengan faktor penyebabnya :
a) Nasabah meninggal maka mitigasinya berupa mengcover kewajiban dengan asuransi jiwa.
b) Usaha nasabah mengalami kebakaran/musibah lainnya maka mitigasinya berupa meng-cover

kewajiban dengan asuransi kerugian

c) Usaha nasabah menurun, terkena PHK atau kerugian lainnya maka BNI Syariah Cabang Bogor akan melakukan R3 (rescheduling, reconditioning, dan restructuring) terlebih dahulu sebagai restrukturisasi pembiayaan, tindakan ini akan disesuaikan dengan keadaan usaha nasabah.

Adapun penjelasan restrukturisasi pembiayaan sebagai berikut :

1) Rescheduling (penjadwalan kembali), yaitu perubahan jadwal pembayaran kewajiban nasabah atau jangka waktunya dan rescheduling pada BNI Syariah Cabang Bogor dilakukan dengan beberapa ketentuan :

a. Tahun pertama saat diberlakukan rescheduling, nasabah akan menyetor angsuran sesuai dengan kemampuannya/hasil yang diperoleh.

b. Tahun kedua, nasabah akan diminta untuk menyetor angsuran sebesar 75\% dari jumlah angsuran normal.

c. Tahun ketiga, angsuran akan kembali normal seperti sebelum diberlakukan rescheduling.

Rescheduling pada pembiayaan murabahah juga terdapat dalam fatwa Dewan Syari'ah Nasional No. 48/DSNMUI/II/2005 Tentang Penjadwalan Kembali Tagihan Murabahah:

Ketentuan penyelesaian LKS boleh melakukan penjadwalan kembali (rescheduling) tagihan murabahah bagi nasabah yang tidak bisa menyelesaikan/melunasi pembiayaannya sesuai jumlah dan waktu yang telah disepakati, dengan ketentuan :

a) Tidak menambah jumlah tagihan yang tersisa.

b) Pembebanan biaya dalam proses penjadwalan kembali adalah biaya riil. 
c) Perpanjangan masa pembayaran harus berdasarkan kesepakatan kedua belah pihak.

2) Reconditioning(persyaratan kembali), yaitu perubahan sebagian atau seluruh persyaratan pembiayaan, antara lain perubahan jadwal pembayaran, jumlah angsuran, jangka waktu dan/atau pemberian potongan sepanjang tidak menambah sisa kewajiban nasabah yang harus dibayarkan kepada BNI Syariah Cabang Bogor, antara lain meliputi :

a) perubahan jadwal pembayaran;

b) perubahan jumlah angsuran;

c) perubahan jangka waktu;

d) perubahan nisbah dalam pembiayaan mudharabah atau musyarakah;

e) perubahan proyeksi bagi hasil dalam pembiayaan mudharabah atau musyarakah; dan/atau pemberian potongan.

3) Restructuring (penataan kembali), yaitu perubahan persyaratan pembiayaan yang tidak terbatas pada rescheduling atau reconditioning, antara lain meliputi :

a) Penambahan dana fasilitas pembiayaan BNI Syariah Cabang Bogor;

b) konversi akad pembiayaan;

c) konversi pembiayaan menjadi surat berharga syariah berjangka waktu menengah;

d) konversi pembiayaan menjadi penyertaan modal sementara pada perusahaan nasabah.

Berdasarkan penjelasan mekanisme penyelamatan pembiayaan bermasalah di atas, pada penerapan di BNI Syariah Cabang Bogor sudah sesuai dengan ketetapan Peraturan Bank Indonesia Nomor 13/9/PBI/2011 tentang perubahan atas Peraturan Bank Indonesia Nomor 10/18/PBI/2008 tentang restrukturisasi pembiayaan bagi Bank Umum Syariah (BUS) dan Unit Usaha Syariah (UUS).

Dari tindakan restrukturisasi pembiayaan dapat diketahui bahwa BNI Syariah Cabang Bogor tetap memberikan keringanan-keringanan yang dapat memudahkan nasabah dalam melunasi tunggakan pembayaran angsuran. Selain itu, BNI Syariah Cabang Bogor juga tetap menjaga hubungan baik dengan nasabah pembiayaan bermasalah pada saat tindakan restrukturisasi pembiayaan. Hal itu juga menjadi salah satu pengaruh dalam meningkatkan kualitas layanan terhadap nasabah, restrukturisasi pembiayaan juga tergambar dalam Al-Qur'an Surat Al-Baqarah ayat 280 yaitu :

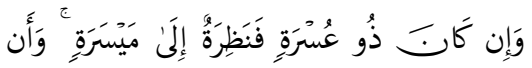

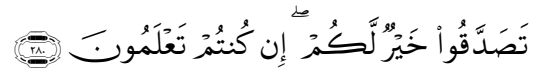

Artinya: "dan jika (orang berhutang itu) dalam kesukaran, maka berilah tangguh sampai dia berkelapangan. Dan menyedekahkan (sebagian atau semua hutang) itu lebih baik bagimu, jika kamu mengetahui" (QS. Al Baqarah : 280).

Setelah dilakukan restrukturisasi pembiayaan berupa R3 (rescheduling, reconditioning, dan restructuring), selanjutnya BNI Syariah Cabang Bogor melakukan monitoring terhadap usaha nasabah agar tetap terjaga baik. Dalam melakukan monitoring ini, pihak BNI Syariah Cabang Bogor akan memperhatikan perkembangan usaha nasabah pasca restrukturisasi pembiayaan.

Tindakan R3 (rescheduling, reconditioning, dan restructuring) pada BNI Syariah Cabang Bogor diberikan kepada nasabah yang masih mempunyai iktikad baik (kooperatif) untuk melunasi kewajibannya, kebijakan ini 
juga sesuai dengan PBI Nomor 13/9/PBI/2011 Pasal 5. Adapun nasabah yang tidak mempunyai iktikad baik untuk melunasi angsurannya atau tidak adanya prospek usaha nasabah serta nasabah tidak kooperatif untuk menyelesaikan pembiayaan atau upaya penyelamatan, dengan upaya restrukturisasi tidak membawa hasil melancarkan kembali pembiayaantersebut. Maka upaya penyelesaian pembiayaan bermasalah BNI Syariah Cabang Bogor dengan cara eksekusi jaminan/pemutusan hubungan dengan dua cara yaitu :

1) Penjualan aset dibawah tangan

2) Lelang

Jika dari hasil eksekusi jaminan ternyata melebihi kewajiban nasabah, maka BNI Syariah Cabang Bogor akan mengembalikan kembali sisa lelang tersebut kepada nasabah dengan pengurangan biaya lelang terlebih dahulu.

Kebijakan BNI Syariah Cabang Bogor dalam eksekusi jaminan/pemutusan hubungan pembiayaan sudah seuai dengan Undang-Undang Perbankan Syariah Pasal 40 yaitu bank syariah dan UUS dapat membeli sebagian atau seluruh agunan, baik melalui maupun di luar pelelangan, berdasarkan penyerahan secara sukarela oleh pemilik agunan atau berdasarkan pemberian kuasa untuk menjual dari pemilik agunan, dengan ketentuan agunan yang dibeli tersebut wajib dicairkan selambat-lambatnya dalam jangka waktu 1 (satu) tahun. Dalam hal harga pembelian agunan melebihi jumlah kewajiban nasabah kepada bank syariah dan UUS, selisih kelebihan jumlah tersebut harus dikembalikan kepada nasabah setelah dikurangi dengan biaya lelang dan biaya lain yang terkait langsung dengan proses pembelian agunan.Kebijakan BNI Syariah Cabang Bogor juga sesuai dengan fatwa Dewan Syari'ah Nasional No. 47/DSN-MUI/II/2005.

Seluruh tindakan pengelolaan risiko pembiayaan, baikrestrukturisasi pembiayaan maupun pemutusan hubungan diupayakan dalam rangka menekan persentase NPF (Non Performing Financing) setiap tahunnya sesuai standar Peraturan Bank Indonesia Nomor 09/01/PBI/2007 tentang tingkat kesehatan bank syariah maksimum sebesar 5\%, apabila nilai NPF melampaui 5\% maka bank tersebut dianggap memiliki risiko pembiayaan yang cukup tinggi. Dengan beberapa strategi yang diterapkan maka BNI Syariah dapat menekan persentase NPF setiap tahunnya, seperti tertera dalam

\begin{tabular}{lccccc}
\hline \multirow{2}{*}{ Kategori } & \multicolumn{5}{l}{ Persentase (\%) } \\
\cline { 2 - 6 } & $\mathbf{2 0 1 4}$ & $\mathbf{2 0 1 3}$ & $\mathbf{2 0 1 2}$ & $\mathbf{2 0 1 1}$ & $\mathbf{2 0 1 0}$ \\
NPF & 1,88 & 1,86 & 2,02 & 3,62 & 3,59 \\
Gross & & & & & \\
NPF & 1,04 & 1,13 & 1,42 & 2,42 & 1,92 \\
Nett &
\end{tabular}

tabel berikut :

Tabel 2. Persentase NPF BNI Syariah Tahun 2010-2014

\section{Sumber : Diolah dari Annual Report BNI} Syariah

Berdasarkan tabel di atas tergambar bahwa NPF BNI Syariah setiap tahunnya semakin menurun dan dalam posisi aman, namun walaupun NPF BNI Syariah masih dalam posisi aman yaitu di bawah $5 \%$ tetap harus dimitigasi dan dikelola, karena NPF merupakan risiko pembiayaan yang jika tidak ditanggulangi akan berdampak pada operasional lainnya, salah satunya akan berdampak pada pemberian porsi bagi hasil nasabah yang menitipkan dananya untuk dikelola (DPK).

NPF BNI Syariah Cabang Bogor masih didominasi oleh pembiayaan produktif karena kapasitas pembiayaan produktif jauh lebih besar dibandingkan dengan pembiayaan konsumtif. Pembiayaan 
konsumtif pada BNI Syariah Cabang Bogor dimulai dari Rp. 250 juta - Rp. 2 $\mathrm{M}$, sedangkan untuk pembiayaan produktif dimulai dari Rp. $1 \mathrm{M}$ - Rp. 3M.

Berikut merupakan kendala-kendala telatnya nasabah membayarkan angsurannya kepada BNI Syariah Cabang Bogor, terutama terdapat pada kondisi usaha maupun nasabahnya sendiri, antara lain:

1) Jika nasabah seorang pengusaha, maka faktor utama penyebab angsuran pembiayaan menjadi bermasalah adalah kondisi usaha nasabah yang sedang menurun sehingga nasabah tidak mampu membayar sesuai dengan jumlah yang ditetapkan.

2) Jika nasabah seorang karyawan, maka kondisi perusahaan tempat nasabah bekerja yang terkadang menjadi faktor penyebabnya, perusahaan mengalami kebangkrutan sehingga nasabah terkena PHK.

3) Ada juga nasabah yang dananya tidak cukup untuk membayar angsuran karena dipinjam oleh teman/orang lain dan belum dikembalikan.

4) Adanya nasabah yang menggunakan dana pembiayaan bukan untuk keperluan usaha, tetapi digunakan untuk keperluan konsumtif. Kendalakendala tersebut terkadang terhambat penyelesaiannya karena nasabah sulit untuk dihubungi atau ditemui sehingga pihak BNI Syariah Cabang Bogor harus mencari waktu yang tepat agar bertemu dengan nasabah. Dengan adanya hambatan tersebut maka dapat disimpulkan bahwa nasabah yang termasuk ketegori NPF merupakan salah satu nasabah yang bermasalah dalam proses monitoring.

Kendala-kendala dalam

permasalahan pembiayaan dapat diselesaikan dengan beberapa strategi, antara lain :
1) Kenali nasabah dan permasalahannya (Pendekatan Persuasif).

2) Mencari solusi penyelesaian permasalahan pembiayaan.

Monitoring yang dilakukan BNI Syariah Cabang Bogor untukperusahaan mikro dan corporate cenderung sama, yang berbeda hanya dari segi penanganannya, perusahaan corporate lebih kompleks dalam waktu penanganan pembiayaan yang bermasalah. Untuk perusahaan corporate terkadang terdapat kendala berupa sulitnya nasabah untuk dihubungi dan ditemui, bahkan untuk informasi yang bersumber dari relasi atau mitra bisnis dan supplier cenderung juga mengalami kesulitan untuk dihubungi, berbeda dengan perusahaan mikro atau UKM yang lebih udah untuk dimintai informasi.

\section{Tingkat Efektivitas Proses Ex-Ante Screening dan Ex-Post Monitoring}

Analis unit SME (Small Medium Enterprise) atau unit pembiayaan produktif menyatakan proses ex-ante screening merupakan awal proses yang terpenting karena proses tersebut akan menentukan dan meminimalisir risiko yang akan terjadi. Analisis merupakan awal di mana BNI Syariah Cabang Bogor mengetahui gambaran usaha yang dijalankan calon nasabah, baik dari sektor usaha, proses bisnis, produk memiliki banyak kompetitor atau tidak, performance usaha, strategi promosi, penjualan dan respon masyarakat terhadap usaha tersebut. Artinya ketika suatu pembiayaan tidak melewati proses analisis maka akan mengakibatkan risiko yang fatal, sebaik apapun perangkat monitoring yang dimiliki bank syariah namun ketika tidak dilakukan proses screening maka akan menimbulkan risiko yang besar dan perlahan akan memicu risiko-risiko yang lainnya. 
Proses ex-ante screening atau analisis pembiayaan pada BNI Syariah Cabang Bogor sudah efektif namun untuk mengantisipasi risiko yang tidak diharapkan maka sebaiknya BNI Syariah Cabang Bogor melakukan survei kondisi usaha sebelum pembiayaan diberikan.

Proses ex-ante screening yang sudah baik dan efektif harus diimbangi dengan ex-postmonitoring yang baik pula, namun dari hasil penelitian diketahui adanya permasalahan pembiayaan berupa penggunaan dana pembiayaan diluar perjanjian, hal ini menunjukan adanya moral hazard nasabah. Moral hazard timbul setelah pembiayaan diberikan, yang mengindikasikan perlunya proses monitoring pembiayaan yang ketat dan intens sehingga ancaman moral hazard dapat dihindarkan.

\section{Kaidah Fiqih Mengenai Penerapan Ex-Ante Screening dan Ex-Post Monitoring}

Risiko pembiayaan merupakan risiko yang disebabkan oleh tidak terpenuhinya kewajiban nasabah pada bank syariah, ketika risiko pembiayaan terjadi maka akan berdampak pada operasional bank syariah lainnya dan perlahan akan menjadi risiko secara systemic. Untuk menanggulangi risiko tersebut maka bank syariah menggunakan dua proses berupa $e x-$ ante screening dan ex-post monitoring. Dalam ushul fiqih terdapat kaidah yang mewakili penerapan ex-ante screening dan ex-post monitoring di bank syariah, berikut merupakan kaidah tersebut:

\section{"Kemadharatan harus dihilangkan"}

Kaidah di atas menunjukan adanya upaya dalam menghilangkan kemudharatan, kaidah ini juga memberikan solusi ketika suatu mudharat terjadi, maka tindakantindakan yang tepat harus diambil untuk menghilangkan mudharat tersebut (Mansoori, 2009). Adapun dalam praktik perbankan syariah, risiko tidak dapat dihilangkan secara menyeluruh, risiko hanya dapat dikelola dan diminimalisir agar kemudharatan tidak berdampak pada operasional lainnya. Proses ex-ante screening dan expost monitoring secara umum bertujuan untuk meraih kemaslahatan dan menolak kemafsadatan akibat dari tidak terpenuhinya kewajiban nasabah atau NPF (Non Performing Financing). Proses ini pula untuk merealisasikan maqashid al-syari'ah, menghilangkan mudharat juga telah dijelaskan dalam beberapa potongan ayat dalam Al-Qur'an :

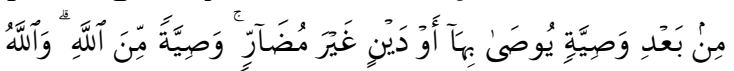

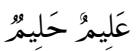

Artinya : “......., sesudah dipenuhi wasiat yang dibuat olehnya atau sesudah dibayar hutangnya dengan tidak memberi mudharat (kepada ahli waris). (Allah menetapkan yang demikian itu sebagai) syari'at yang benar-benar dari Allah, dan Allah Maha mengetahui lagi Maha Penyantun (QS. AnNisa : 12)

\section{KESIMPULAN DAN IMPLIKASI}

1. Prosedur ex-ante screening dalam upaya pengelolaan risiko pembiayaan, baik pembiayaan produktif maupun konsumtif pada BNI Syariah Cabang Bogor dilakukan dengan prinsip analisis 5C (Character, Capacity, Capital, Condition Collateral), 5P (Personality, Purpose, Prospect, Payment, Party) dan 3R (Return, Repayment, Risk Bearing Activity). Teknik pengumpulan data dalam analisis tersebut berupa pengumpulan dokumen persyaratan pembiayaan dan hasil wawancara dengan calon nasabah. Selain analisis 5C, 5P dan 
3R, Kantor Pusat BNI Syariah juga memberikan traffic light (pedoman/rambu-rambu sektor usaha yang aman) pada setiap Kantor Cabang dalam memberikan pembiayaan, faktor pendukung lain berupa perangkat audit kepatuhan khusus yang dimudahkan dengan sistem EFO (Electronic Financing Origination), dan pemantauan DPS (Dewan Pengawas Syariah) dalam operasional BNI Syariah.

2. Proses ex-post monitoring BNI Syariah Cabang Bogor dilakukan dengan credit checking (pemantauan angsuran), on desk monitoring (pemantauan administratif), on site monitoring (survei lapangan) dan trade checking (informasi pihak ketiga). Ketika hasil monitoring menunjukkan adanya permasalahan pembiayaan maka BNI Syariah Cabang Bogor akan melakukan pengelompokkan kriteria kolektibilitas nasabah yaitu Lancar, Dalam Perhatian Khusus, Kurang Lancar, Diragukan dan Macet. Penyelesaian permasalahan pembiayaan tersebut berupa penerapan R3 yaitu rescheduling (penjadwalan kembali), reconditioning(persyaratan

kembali), dan restructuring (penataan kembali). Bagi nasabah yang tidak mempunyai iktikad baik untuk melunasi angsurannya maka BNI Syariah melakukan tindakan berupa pemutusan hubungan dengan dua cara berupa penjualan aset dibawah tangan dan lelang.

3. Ex-ante screening dan ex-post monitoring merupakan prosedur pembiayaan yang sangat penting dan saling berkaitan bagi pengelolaan risiko di BNI Syariah Cabang Bogor, sehingga keduanya harus dijalankan sesuai dengan SOP yang telah ditetapkan. Dari kedua prosedur tersebut, ex-ante screening merupakan awal proses terpenting dalam pembiayaan karena proses tersebut akan menentukan dan meminimalisir risiko yang akan terjadi. Analisis pembiayaan merupakan awal dimana BNI Syariah Cabang Bogor mengetahui gambaran usaha yang dijalankan calon nasabah, baik dari sektor usahanya maupun karakter nasabah dalam lingkungan usaha.

\section{DAFTAR PUSTAKA}

Bank Indonesia. 2007.Peraturan Bank Indonesia Nomor 9/1/PBI/2007 Tentang Sistem Penilaian Tingkat Kesehatan Bank Umum Berdasarkan Prinsip Syariah. Diakses darihttp://www.bi.go.id

Bank Indonesia. 2011. Peraturan Bank Indonesia Nomor 13/9/PBI/2011 2008 Tentang Restrukturisasi Pembiayaan Bagi Bank Umum Syariah (BUS) dan Unit Usaha Syariah (UUS).Diakses darihttp://www.bi.go.id

Bank Indonesia. 2011. Peraturan Bank Indonesia Nomor 13/23/PBI/2011 Tentang Penerapan Manajemen Risiko Bagi Bank Umum Syariah dan Unit Usaha Syariah. Diakses darihttp://www.bi.go.id

Bank Indonesia. 2011.Peraturan Bank Indonesia Nomor 13/2/PBI/2011 Tanggal 12 Januari 2011 Tentang Pelaksanaan Fungsi Kepatuhan Bank Umum.Diakses darihttp://www.bi.go.id

Bank Indonesia. 2011.Peraturan Bank Indonesia Nomor 
13/13/PBI/2011 Tentang Penilaian Kualitas Aktiva Bagi Bank Umum Syariah dan Unit Usaha Syariah.Diakses darihttp://www.bi.go.id

Bank Indonesia.2012.Peraturan Bank Indonesia Nomor 14/20/PBI/2012 Tentang Fasilitas Pendanaan Jangka Pendek Syariah Bagi Bank Umum Syariah. Diakses darihttp://www.bi.go.id

Buchori, Ahmad, dkk. 2003. Tim Penelitian dan Pengembangan Direktorat Perbankan syariah, Bank Indonesia.

Dewan Syari'ah Nasional. 2005. Fatwa DSN No. 48/DSNMUI/II/2005 Tentang Penjadwalan Kembali Tagihan Murabahah. Diakses dariwww.dsnmui.or.id
Mansoori, Muhammad Tahir. 2009. Kaidah-Kaidah Fiqih Keuangan dan Transaksi Bisnis. Bogor : Ulil Albaab Institute.

Otoritas Jasa Keuangan. 2013. Laporan Perkembangan Keuangan Syariah Tahun $2013 . \quad$ Diakses dariwww.ojk.go.id

Rochman, Fatchur. 2010. Analisis Pengukuran Risiko Pembiayaan Murabahah dengan Menggunakan Credit Risk : Studi Kasus BNI Syariah. Tesis. Jakarta : Fakultas Ekonomi Universitas Indonesia.

Sugiyono. 2010. Metode Penelitian Bisnis. Bandung : Alfabeta.

Trihantana, Rully. 2014. Manajemen Risiko. Materi Kuliah. Bogor : Program Studi Ekonomi Islam Fakultas Ekonomi Islam Universitas Djuanda Bogor. 
Jurnal Nisbah Volume 1 Nomor 22015 | 132 